УДК 342.951

DOI https://doi.org/10.32837/apdp.v0i87.2793

Д. В. Бабенко

\title{
СПЕЦИФІКА АДМІНІСТРАТИВНО-ПРАВОВОГО РЕГУЛЮВАННЯ ДІЯЛЬНОСТІ ГОСПОДАРСЬКИХ ТОВАРИСТВ
}

Постановка проблеми. Загальновідомо, що з моменту проголошення незалежності України й дотепер триває безупинний розвиток вітчизняної системи підприємництва, що приводить до невпинного збільшення як тих, що вже існують, так і новоутворених корпорацій. Вдала комерційна діяльність, за успішного підходу до менеджменту організації, наділяє власників та управлінців як перспективами, так i реальними можливостями підвищення свого матеріального становища, щороку приваблює левову долю охочих мати свою справу.

На розвиток суб'єктів господарювання, безсумнівно, впливають багато чинників, серед яких, окрім ступеня конкуренції та рівня ринкових відносин, існують вимоги, що відображаються в соціальних потребах, продиктованих суспільством. Багато чинників визначаються і впроваджуються у правомочностях уповноважених компетентних органів - носіїв публічних інтересів. Державна політика, яка характеризується наданням підприємцям обумовленого обсягу свобод та диспозитивності, залишає за собою державний нагляд (контроль) у приватному секторі економіки, а політико-правова організація суспільства повинна забезпечувати реальні можливості функціонування підприємств, гарантувати безпеку та захист учасників господарських відносин від свавільного позбавлення їх капіталу і власності.

Водночас діяльність суб'єктів господарювання сприяє невпинному зростанню залучення грошових та матеріальних активів у різні сфери господарства, підвищенню благополуччя та достатку суспільства. Саме великі корпоративні підприємства є найбільшими платниками податків, що є значним джерелом фінансових надходжень до державного бюджету України й осередком створення нових робочих місць.

Оцінка стану літератури. Аналогічні питання неодноразово ставали предметом розгляду багатьох вітчизняних та закордонних фахівців у галузі права. Так, загальним проблемам адміністративного права, державного управління та контролю присвячено чимало наукових досліджень. Зокрема, вказаним питанням приділялася особлива увага у працях В.Б. Авер'янова, М.І. Ануфрієва, О.М. Бандурки, В.О. Заросила, В.К. Колпакова, В.М. Селіванова, А.М. Чорної та інших; аспекти захисту, дотримання конституційних прав, свобод, законних інтересів фізичних та юридичних осіб досліджували М.І. Ануфрієв, Т.О. Коломоєць, Ю.А. Компанієць, В.В. Копєйчиков, Н.М. Пархоменко, О.Ф. Скакун тощо; аналізу діяльності корпоративних підприємств та їхньої взаємодії із суб'єктами владних повноважень присвячувались наукові роботи О.В. Гарагонича, І.В. Дроздової, О.Р. Кібенко, А.С. Мацка, М.В. Руденка, І.В. Спасибо-Фатєєвої, Ю.О. Тихомирова, В.С. Шестак та інших. 
Метою статті є узагальнення теоретичних положень, аналіз судової практики та дослідження стану адміністративно-правового регулювання діяльності корпоративних підприємств в Україні.

Результати дослідження. Держава забезпечує нормальний розвиток суспільства та багатьох його соціальних груп через застосування влади та правового впливу, а права - через нормативне регулювання. Проте передумови створення, встановлення основ і засад діяльності, правових механізмів функціонування комерційних підприємств як сукупності людей, об'єднаних спільною метою, віднесені до компетенції органу законотворення - Верховної Ради України, а деякі компетенції розподілені серед конкретних суб'єктів владних повноважень. До них пунктом 7 частини 1 статті 4 Кодексу адміністративного судочинства України, віднесені органи державної влади (зокрема, без статусу юридичної особи), органи місцевого самоврядування, їх посадові чи службові особи, інші суб'єкти під час здійснення ними публічно-владних управлінських функцій на підставі законодавства, зокрема й на виконання делегованих повноважень або надання адміністративних послуг [5].

Отже, останні, які є носіями публічних інтересів, наділені компетенцією адміністративно-правового регулювання у сфері господарських та корпоративних відносин.

О.Ф. Скакун зазначає, що правове регулювання - це здійснюване державою за допомогою права і сукупності правових засобів упорядкування суспільних відносин, їх юридичне закріплення, охорона і розвиток [11, с. 450-488].

Отже, у правовій доктрині адміністративно-правове регулювання можна визначити як цілеспрямований процес здійснення безпосереднього впливу держави за допомогою встановлених легітимних засобів (правові засоби), якими наділені суб'єкти владних повноважень, на учасників відповідних правовідносин. Проте, відповідно до статті 19 Конституції України, органи державної влади, місцевого самоврядування та їх посадові особи зобов'язані діяти лише на підставі, у межах повноважень та у спосіб, що передбачені Конституцією та законами України [6].

Однак правові засоби, які застосовуються під час здійснення адміністративно-правового регулювання, є інституційними утвореннями правової дійсності, які у своєму реальному функціонуванні, використанні у процесі правової діяльності приводять до досягнення визначеного результату у вирішенні соціальних завдань і проблем, що постали перед суспільством і державою на визначеному етапі.

На думку Н.М. Пархоменко, до основних способів правового регулювання відносять [12, с. 111-112]:

- дозволи, тобто надання суб'єктам правовідносин можливостей на свої власні позитивні активні дії;

- заборони - покладання на осіб пасивних обов'язків утриматися від здійснення визначеного роду заборонених дій, які чинним законодавством визначаються як протиправні;

- позитивні зобов'язання - запропоновані особам обов'язки здійснення активних позитивних дій, тобто обов’язки активного змісту, які супроводжує «свій набір» правових засобів і які водночас самі виступають ефективними правовими засобами регулювання суспільних відносин. 
На підставі зазначеного вище ми можемо констатувати, що тип адміністративно-правового регулювання для корпоративних підприємств характеризує загальну спрямованість впливу права на суспільні відносини у процесі здійснення підприємницької діяльності останніми, залежно від поєднання двох найбільш суттєвих способів правового регулювання - дозволів і заборон.

Водночас варто зазначити, що наведені вище суб'єкти владних повноважень здебільшого не є безпосередніми учасниками корпоративних правовідносин. Встановлене нормативно-правовими актами їхнє призначення полягає у здійсненні ними контролю за дотриманням корпоративного законодавства й адміністративно-правового втручання для захисту порушених прав учасників корпоративних правовідносин або реалізації управління державними корпоративними правами та наданні адміністративних послуг [1, с. 80-83]. Насамперед публічно-владними суб'єктами корпоративних відносин можуть бути: Міністерство юстиції України, Антимонопольний комітет України, Національний банк України, Національна комісія із цінних паперів та фондового ринку, а також місцеві державні адміністрації тощо.

Водночас, ми вважаємо, що умовно компетенція суб'єктів владних повноважень щодо корпоративних прав поділяється на три великі групи:

1. Повноваження, спрямовані на контроль за дотриманням корпоративного законодавства.

2. Повноваження, спрямовані на захист порушених прав та інтересів активних учасників корпоративних відносин.

3. Повноваження, пов'язані з управлінням державними корпоративними правами.

Упевненим прикладом першої групи повноважень можуть слугувати нещодавні зміни та правові новели законодавства щодо подання передбаченої Законом України «Про державну реєстрацію юридичних осіб, фізичних осіб-підприємців та громадських формувань» інформації щодо кінцевого бенефіціарного власника юридичної особи або про його відсутність.

Згідно зі «Змінами до деяких нормативно-правових актів Міністерства юстиції України», затвердженими наказом Міністерства юстиції України № 1626/5 від 12 травня 2020 р., розділ II Порядку державної реєстрації юридичних осіб, фізичних осіб-підприємців та громадських формувань, що не мають статусу юридичної особи, затвердженого наказом Міністерства юстиції України від 9 лютого 2016 р. № $359 / 5$, доповнено новим пунктом 19, яким встановлено, що в разі виявлення державним реєстратором фактів неподання або несвоєчасного подання юридичною особою передбаченої законом інформації про кінцевого бенефіціарного власника юридичної особи або про його відсутність, або документів на підтвердження відомостей про кінцевого бенефіціарного власника юридичної особи, таким реєстратором, не пізніше наступного робочого дня, інформується територіальний орган Міністерства юстиції України за місцезнаходженням відповідної юридичної особи про виявлення відповідних фактів шляхом надсилання відповідного листа [7].

Нещодавні зміни нормативно-правових актів Міністерства юстиції України наділили державних реєстраторів правомочністю здійснення контролю за сво- 
єчасністю подання керівником підприємства, особою, яка має право вчиняти дії та подавати документи від імені юридичної особи (без довіреності) або уповноваженою особою (за довіреністю чи іншим документом, що підтверджує іï повноваження) відомостей про кінцевого бенефіціарного власника підприємства.

Повноваження, спрямовані на захист порушених прав учасників корпоративних відносин, виконує розгалужена система органів державної влади - від судової системи України до Офісу протидії рейдерству, правоохоронних органів та інших структурних підрозділів держави.

Згідно з підпунктом 4 пункту 3 Положення про Національну комісію із цінних паперів та фондового ринку, одним із її основних завдань є захист прав інвесторів шляхом ужиття заходів щодо запобігання порушенням законодавства на ринку цінних паперів та законодавства про акціонерні товариства і припинення таких із застосуванням відповідних санкцій у межах своїх повноважень [8]. Водночас варто зазначити, що справи про стягнення з учасників фондового ринку штрафів, накладених уповноваженими особами Національної комісії із цінних паперів та фондового ринку, а також про оскарження рішень, дій чи бездіяльності цих осіб підлягають розгляду в порядку адміністративного судочинства як публічно-правові спори на підставі частини першої статті 17 Кодексу адміністративного судочинства України (пункт 8 постанови Пленуму Верховного Суду України «Про практику розгляду судами корпоративних спорів») [9].

Нині функціями управління державними корпоративними правами наділені чимало суб'єктів владних повноважень. Серед них суттєвий вплив здійснює Фонд державного майна України, який реалізує державну політику у сфері приватизації, оренди, використання та відчуження державного майна, менеджменту об’єктів державної власності, зокрема й корпоративних прав держави щодо вказаних об'єктів, які належать до сфери його управління, а також у галузі державного регулювання оцінки майна, майнових прав та професійної оціночної діяльності (частина 1 статті 1 Закону України «Про Фонд державного майна України») [4].

Для запобігання зловживанням та іншим неправомірним діям із боку суб'єктів владних повноважень існують і законодавчі обмеження щодо розпорядження Фондом державного майна України майном юридичної особи. Так, вказані обмеження поширюються виключно на підприємства з корпоративними правами держави в їхньому статутному капіталі в розмірі понад $25 \%$. Велика палата Верховного Суду на підтримку наведеного в постанові від 30 травня 2018 р. у справі № 926/4643/16 звертає увагу на те, що суди попередніх інстанцій, які вирішували спір по суті, встановили, що відносини, які склалися між сторонами, виникли стосовно оренди майна публічного акціонерного товариства, що перебуває у процесі приватизації. У таких відносинах Фонд державного майна України здійснює повноваження власника державного майна у процесі приватизації підприємств, установ і організацій, тобто не реалізує в цій частині владні управлінські функції. Водночас наявність у статутному капіталі господарського товариства державної частки (пакет акцій, що належить державі) не змінюе правового режиму його майна, яке є приватною власністю господарського товариства. Оскільки державі у статутному капіталі відповідача у справі належить 21,524\% акцій, а інші 78,476\% 
акцій є власністю інших акціонерів, наявні законодавчі обмеження щодо розпорядження майном публічного акціонерного товариства, зокрема й щодо передачі його в оренду, порушують права акціонерів, які були гарантовані законодавством України. Застосування Фондом державного майна України таких обмежень є непропорційним і таким, що порушує загальні принципи господарювання в Україні [10].

Висновки. Адміністративно-правове регулювання відносин, що виникають у процесі здійснення юридичними особами приватного права комерційної діяльності, має істотний вплив як на суб'єктів підприємництва, так і на державу. 3'ясовано, що на ефективне функціонування корпоративних підприємств позитивно впливають адміністративно-правові засоби, способи та методи відповідного регулювання наявних правовідносин.

Завданням суб'єктів, що виконують публічно-владні управлінські функції, є встановлення, підтримання й контроль за додержанням загальних та рівних для всіх суб'єктів господарювання умов забезпечення їхньої максимальної спрямованості на задоволення необхідних потреб. В іншому разі порушення законодавства будь-ким з учасників правовідносин має наслідком очевидну невідповідність критеріям законності та порушує справедливий баланс між інтересами корпоративних підприємств і носіями влади.

Перспективи подальших досліджень будуть спрямовані на вивчення специфіки й поетапного упорядкування актуальних аспектів та проблематики правовідносин між суб’єктами владних повноважень та комерційними юридичними особами.

\section{Jimepamypa}

1. Адміністративне право України. Повний курс : підручник / В.В. Галунько та ін. Видання друге. Херсон : Олді-Плюс, 2019. 520 с.

2. Бабенко Д.В. Функціонування корпоративних підприємств як об'єкт адміністративно-правового регулювання в сучасних умовах. Адміністративно-правова доктрина і практика в умовах сучасних викликів : матеріали Міжнародної науково-практичної конференції, м. Київ, 4-5 червня 2020 р., Київський національний університет імені Тараса Шевченка. Київ, 2020. С. 5-9.

3. Державне управління: проблеми адміністративно-правової теорії та практики : посібник / 3 а заг. ред. В.Б. Авер'янова. Київ : Факт, 2003. 384 с.

4. Про Фонд державного майна України : Закон України. URL: https://zakon.rada.gov.ua/laws/ show/4107-17.

5. Кодекс адміністративного судочинства України. URL: https://zakon2.rada.gov.ua/laws/ show/2747-15.

6. Конституція України від 28 червня 1996 р. № 254 к/96-ВР. Відомості Верховної Ради. 1996. № 30. C. 141.

7. Наказ Міністерства юстиції України № 1626/5 від 12 травня 2020 p. URL: https://zakon.rada. gov.ua/laws/show/z0429-20.

8. Положення про Національну комісію із цінних паперів та фондового ринку. URL: https://zakon.rada.gov.ua/laws/show/1063/2011.

9. Про практику розгляду судами корпоративних спорів : постанова Пленуму Верховного Суду України. URL: https://zakon.rada.gov.ua/laws/show/v0013700-08.

10. Постанова Великої палати Верховного Суду від 30 травня 2018 р. у справі № 926/4643/16. URL: http://www.reyestr.court.gov.ua/Review/74506044.

11. Скакун О.Ф. Теорія держави і права : підручник. Харків : Консум, 2001. 656 с.

12. Теорія держави та права : навчальний посібник / Р.А. Ромашов, та ін. ; за заг. ред. Р.А. Ромашова. Київ : КЮІ МВС України, 2005. 131 с. 


\section{Анотація}

Бабенко Д. В. Специфіка адміністративно-правового регулювання діяльності господарських товариств. - Стаття.

Стаття присвячена адміністративно-правовому регулюванню функціонування суб'єктів господарювання та ролі окремих органів державної влади у правовідносинах, що виникають під час взаємодії корпорацій із державою. Встановлено, що адміністративно-правове регулювання розуміємо як цілеспрямований процес здійснення впливу держави в особі їі компетентних органів за допомогою визначених правових засобів на учасників відповідних правовідносин, зокрема і юридичних осіб. 3'ясовано, що призначення суб'єктів владних повноважень під час взаємодії зі сферою господарювання полягає у здійсненні ними контролю за дотриманням корпоративного законодавства й адміністративно-правового втручання для захисту порушених прав учасників корпоративних правовідносин або реалізації управління державними корпоративними правами та надання адміністративних послуг. Фактично, тип адміністративно-правового регулювання для корпоративних підприємств характеризує загальну спрямованість впливу права на суспільні відносини у процесі здійснення підприємницької діяльності.

Здійснено умовний розподіл компетенцій суб'єктів владних повноважень на три великі групи: 1) повноваження, спрямовані на контроль за дотриманням корпоративного законодавства; 2) повноваження, спрямовані на захист порушених прав та інтересів активних учасників корпоративних відносин; 3) повноваження, пов'язані з управлінням державними корпоративними правами.

Окрім того, було уточнено твердження стосовно того, що адміністративно-правове регулювання корпоративних правовідносин має істотний вплив як на всебічну діяльність держави, так і на всіх задіяних у цьому процесі суб’єктів господарювання (підприємницькі та некомерційні суб’єкти). Також досліджено, що на ефективне функціонування корпоративних підприємств позитивно впливають адміністративно-правові засоби, способи та методи відповідного регулювання наявних правовідносин.

3'ясовано, що суттєвим завданням суб'єктів, які виконують публічно-владні управлінські функції, є встановлення, підтримання й контроль за додержанням загальних та рівних для всіх суб'єктів господарювання умов забезпечення їхньої максимальної спрямованості на задоволення чинних необхідних потреб. В іншому разі порушення законодавства будь-ким з учасників правовідносин має наслідком очевидну невідповідність критеріям законності та порушує справедливий баланс між інтересами корпоративних підприємств та носіями влади.

Ключові слова: акціонерні товариства, адміністративно-правове регулювання, господарські товариства, корпоративні підприємства, правове регулювання, публічно-владні управлінські функції, суб’єкти владних повноважень.

\section{Summary}

Babenko D. V. Specifics of administrative and legal regulation of companies. - Article.

The article is devoted to the administrative and legal regulation of the functioning of economic entities and the role of individual public authorities in the legal relations that arise in the interaction of corporations with the state. It is established that under the administrative and legal regulation should be seen as a purposeful process of exercising state influence in the face of its competent authorities through certain legal means on the participants of the relevant legal relations, including legal entities. It was found that the purpose of the subjects of power in cooperation with the business sector is to monitor compliance with corporate law and administrative and legal intervention to protect the violated rights of corporate parties or the implementation of state corporate rights management and administrative services. In fact, the type of administrative and legal regulation for corporate enterprises characterizes the general direction of the impact of law on public relations in the process of doing business.

The conditional division of competencies of subjects of power into three large groups has been carried out: 1) powers aimed at monitoring compliance with corporate legislation; 2) powers aimed at protecting the violated rights and interests of active participants in corporate relations; 3) powers related to the management of state corporate rights.

In addition, the statement was clarified that the administrative and legal regulation of corporate relations has a significant impact on the comprehensive activities of the state, and for all involved in this process of business entities (business and non-profit entities). It is also investigated that the effective functioning of corporate enterprises is positively influenced by administrative and legal means, methods and techniques of appropriate regulation of existing legal relations.

It was found that the essential task of entities performing public authority management functions is to establish, maintain and control compliance with the general and equal for all business entities conditions to ensure their maximum focus on meeting the existing needs. In other cases, the violation of the law by any of the participants in the legal relationship results in a clear non-compliance with the criteria of legality and disturbs the fair balance between the interests of corporate enterprises and the authorities.

Key words: joint-stock companies, administrative-legal regulation, business associations, corporate enterprises, legal regulation, public-power administrative functions, subjects of power. 